\title{
Giant Cell Angiofibroma in Unusual Localization: A Case Report
}

\author{
Emel Ebru Pala, Rafet Beyhan, Umit Bayol, Suheyla Cumurcu, and Ulku Kucuk
}

Pathology Department, Tepecik Training and Research Hospital, Yenisehir, Izmir, Turkey

Correspondence should be addressed to Emel Ebru Pala, emelozkok@yahoo.com

Received 9 February 2012; Accepted 4 March 2012

Academic Editors: F. Fan, H. Kuwabara, H.-J. Ma, and D. Miliaras

Copyright () 2012 Emel Ebru Pala et al. This is an open access article distributed under the Creative Commons Attribution License, which permits unrestricted use, distribution, and reproduction in any medium, provided the original work is properly cited.

Giant cell angiofibroma (GCA) was initially described as a potentially recurrent tumor in the orbit of adults. However, it is now recognized that it can also present in other locations. The morphological hallmark is a richly vascularized patternless spindle cell proliferation containing pseudovascular spaces and floret like multinucleate giant cells. Our case was a 32-years-old female complaining of painless solitary nodule arising on the occipital region of the scalp, which was diagnosed as giant cell angiofibroma. We report the case because of its extremely rare localization.

\section{Introduction}

A giant cell rich form of hemangiopericytomas-solitary fibrous tumors (HPC-SFT) was described by Dei Tos as giant cell angiofibroma (GCA) [1]. Although originally identified in the orbital region, this tumor may occur in diverse locations. GCAs are well-circumscribed variably encapsulated, small (median, $3 \mathrm{~cm}$ ) lesions. Extraorbital tumors tend to be larger than orbital tumors. Haemorrhagic and cystic changes may be observed on the cut section. It shows histologic appearances intermediate between solitary fibrous tumor and giant cell fibroblastoma of soft tissue. It is characterized by the presence of cellular and sclerosing areas, keloidal collagen deposition, thick-walled vessels, and multinucleated giant stromal cells often lining pseudovascular spaces. Mitotic activity ranged from 1 to 3 mitoses/10 high-power fields. Treatment of GCA consists of simple tumorectomy.

\section{Case Report}

We present a 32-year-old female complaining of painless solitary nodule arising on the occipital region of the scalp. When she first noticed the nodule two years ago, it was $13 \mathrm{~mm}$. After 4 months the size of the nodule became $17 \mathrm{~mm}$. A year later, superficial soft tissue ultrasonography revealed a $24 \times 10 \mathrm{~mm}$ solid subcutaneous mass with hyperechogenic, heterogeneous density. And it was totally excised by a plastic surgeon. Her medical history did not show any distinctive features. On macroscopic examination, red-brown, $25 \times 15$ $\times 6 \mathrm{~mm}$ mass showed well-defined margins. Microscopic examination revealed a subcutaneous well-circumscribed mass, consisting of both cellular areas with especially ovalround-to-spindle-shaped cells intermixed with floret like giant cells in a patternless pattern and hypocellular areas together (Figures 1, 2, and 3). Giant cells often lined the pseudovascular spaces. The lesion was highly vascularized with varying caliber of blood vessels and involved perivascular hyalinization (Figure 4). Also we noticed subcapsular hemorrhage due to the surgical procedure. There was a small group of mononuclear inflammatory cells around pseudovascular spaces. The cells had vesicular chromatin, indistinct nucleoli, and eosinophilic cytoplasm with indistinct cell borders. Necrosis and cytologic atypia were absent. The number of mitotic figures was 2 per $10 \mathrm{HPFs}$. The cells were not encircled by reticulin fibers. Immunohistochemistry showed strong CD34 (Figure 5), bcl-2 (Figure 6), vimentin reactivity and focal CD99 positivity. S100, Desmin, SMA, CD117, $\mathrm{CD} 31$, and CD68 were negative. Ki 67 proliferation index was $2 \%$.

\section{Discussion}

GCA is a condition that represents the transitional stages within the HPC/SFT spectrum. It is accepted as a variant of HPC/SFT. It displays all features of a classic SFT but is identified by pseudovascular spaces lined by multinucleated 


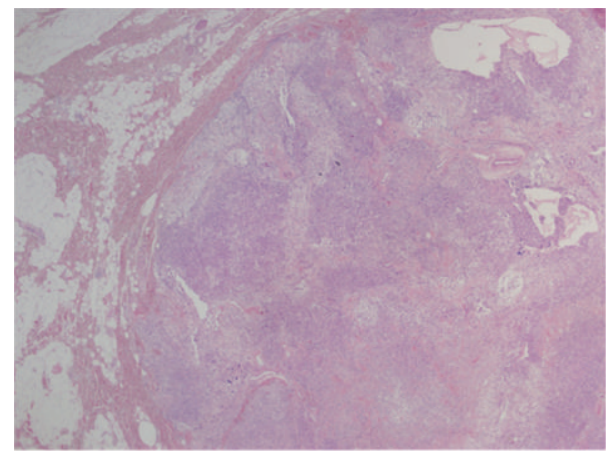

FIgURE 1: Well circumscribed subcutaneous tumor mass $(\mathrm{HE}, \times 40)$.

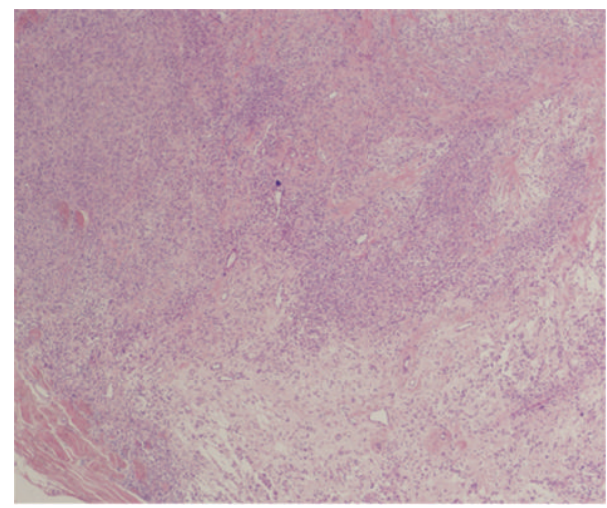

FIgURE 2: Admixture of hypocellular and hypercellular areas $(\mathrm{HE}, \times 100)$.

stromal giant cells. HPC, SFT, giant cell fibroblastoma (GCF), and GCA are CD34 (+) fibroblastic soft tissue tumors. And these tumors have a spectrum of overlapping morphologic and immunophenotypic findings. GCA is a slowly growing soft tissue mass. Although it is a distinctive orbital soft tissue tumor, it can also present in other locations, including head and neck, back, retroperitoneum, hip, vulva, axillary-inguinal regions, posterior mediastinum, and oral cavity. Microscopic examination reveals cellular spindle cell proliferation between hyalinized blood vessels and scattered multinucleated floret like giant cells. Mononuclear and multinucleated stromal cells are characteristically positive for vimentin, CD34, CD99 and, less frequently bcl2, but negative for muscle specific actin, desmin, CD31, CD117, S100. GCF is one of the main entity in the differential diagnosis of GCA. GCF was first described in 1982 as a juvenile form of dermatofibrosarcoma protuberans (DFSP) [2]. GCF and DFSP show same translocation. GCF develops as a painless nodule in the dermis/subcutis. It mainly affects infants and children (median age: 3 ). They are ill-defined, infiltrative masses which composed of hypocellular areas with spindle/giant cells also DFSP-like storiform areas. Most of the GCFs express CD34. Recurrences have often developed but metastases have not been reported [3]. We should also think of fibrous histiocytoma (FH) in the differential diagnosis. But FHs are usually solitary dermal nodules with irregular penetration of the subcutis at the deep border. And the overlying epidermis frequently shows some degree of hyperplasia. In contrast to GCA, CD34 is absent within lesional cells of FH. As our case was a young adult and had a well-defined CD34 (+) tumor without any atypia, our diagnosis was GCA.

Furusato et al. [4] reviewed and analyzed 41 fibroblastic orbital tumors which originally were diagnosed as hemangiopericytomas (16/41), fibrous histiocytomas (9/41), mixed hemangiopericytoma/fibrous histiocytoma (14/41), and giant cell angiofibroma (2/41) of orbit. After histologic and immunohistochemical (CD34, CD99, bcl2, Ki67, p53) review, all cases were reclassified as solitary fibrous tumor. The results of this study suggested that these entities share overlapping morphologic and immunohistochemical features and should be designated as solitary fibrous tumors.

Sonobe et al. [5] detected abnormalities of chromosome 6 with a common pattern involving $6 q 13$ together with other chromosomal aberrations in a typical case of giant cell angiofibroma. This was the first reported case of giant cell angiofibroma demonstrating chromosomal abnormalities. Qian et al. [6] reported a case of GCA in the neck whose chromosome analysis showed a karyotype with $\mathrm{t}(12 ; 17)(\mathrm{q} 15 ; \mathrm{q} 23), \operatorname{del}(18)(\mathrm{q} 21)$ in all 20 cells analyzed. This was the second case of GCA with chromosomal aberrations and the first case of GCA with $\mathrm{t}(12 ; 17)$ occurring as an extraorbital mass. This cytogenetic abnormality in GCA is different from the $\mathrm{t}(17 ; 22)$ ( $\mathrm{q} 22 ; \mathrm{q} 13)$ found in related lesions, such as giant cell fibroblastoma and solitary fibrous tumor, none of which has a specific chromosomal abnormality. 


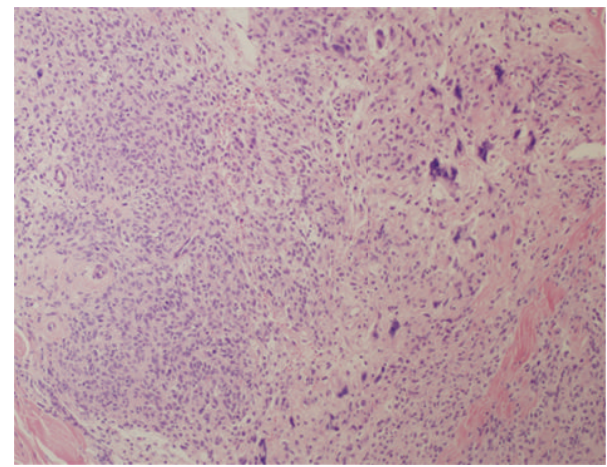

Figure 3: Patternless giant cell and spindle cell proliferation $(\mathrm{HE}, \times 100)$.

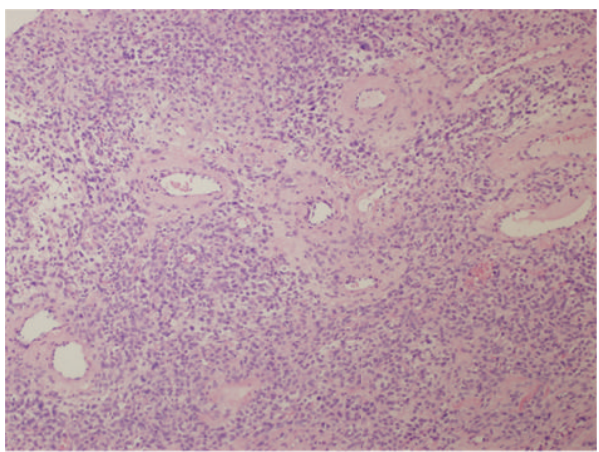

Figure 4: Prominent perivascular hyalinization $(\mathrm{HE}, \times 100)$.

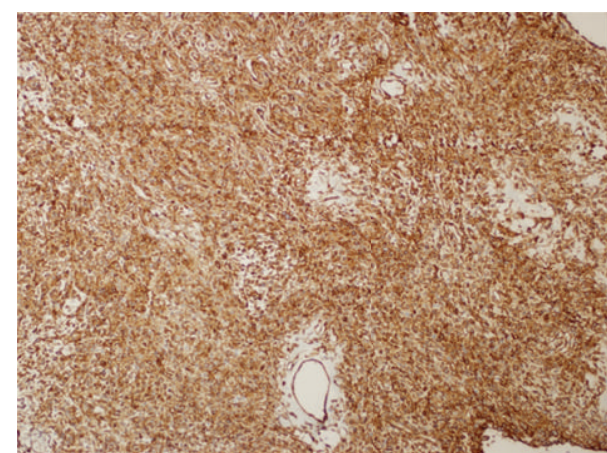

FIgURe 5: Diffuse CD34 positivity in tumor cells $(\mathrm{DAB}, \times 100)$.

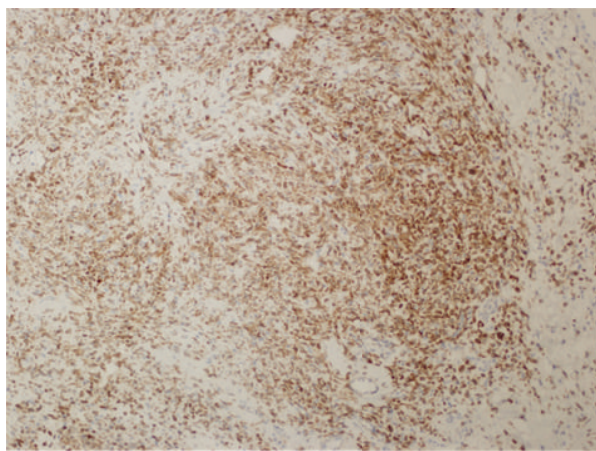

FIGURE 6: Bcl2 positivity in tumor cells $(\mathrm{DAB}, \times 100)$.
There are nearly 25 cases of extraorbital GCA in the literature [7-10]. Thomas et al. [8] reported four extraorbital GCA cases: two in the groin, one in axillary soft tissue, and one in parotid. Electron microscopy showed fibroblastic features in all cases and schwannian features in one case. All of the patients were well without recurrent disease on followup.

Besides the rarity, GCA should be kept in mind when the histopathologic examination reveals a well-defined fibroblastic patternless, CD34 (+) subcutaneous tumor mass.

\section{References}

[1] A. P. Dei Tos, S. Seregard, E. Calonje, J. K. C. Chan, and C. D. M. Fletcher, "Giant cell angiofibroma: a distinctive orbital tumor in adults," American Journal of Surgical Pathology, vol. 19, no. 11, pp. 1286-1293, 1995.

[2] B. M. Shmookler, F. M. Enzinger, and S. W. Weiss, "Giant cell fibroblastoma. A juvenile form of dermatofibrosarcoma protuberans," Cancer, vol. 64, no. 10, pp. 2154-2161, 1989.

[3] P. Jha, C. Moosavi, and J. C. Fanburg-Smith, "Giant cell fibroblastoma: an update and addition of 86 new cases from the Armed Forces Institute of Pathology, in honor of Dr. Franz M. Enzinger," Annals of Diagnostic Pathology, vol. 11, no. 2, pp. 81-88, 2007.

[4] E. Furusato, I. A. Valenzuela, J. C. Fanburg-Smith et al., "Orbital solitary fibrous tumor: Encompassing terminology for hemangiopericytoma, giant cell angiofibroma, and fibrous histiocytoma of the orbit: Reappraisal of 41 cases," Human Pathology, vol. 42, no. 1, pp. 120-128, 2011.

[5] H. Sonobe, J. Iwata, T. Komatsu et al., "A giant cell angiofibroma involving 6q," Cancer Genetics and Cytogenetics, vol. 116, no. 1, pp. 47-49, 2000.

[6] Y. W. Qian, R. Malliah, H. J. Lee, K. Das, N. Mirani, and M. Hameed, "A t(12;17) in an extraorbital giant cell angiofibroma," Cancer Genetics and Cytogenetics, vol. 165, no. 2, pp. 157-160, 2006.

[7] L. Guillou, S. Gebhard, and J. M. Coindre, "Orbital and extraorbital giant cell angiofibroma: A giant cell-rich variant of solitary fibrous tumor?: Clinicopathologic and immunohistochemical analysis of a series in favor of a unifying concept," American Journal of Surgical Pathology, vol. 24, no. 7, pp. 971979, 2000.

[8] R. Thomas, S. S. Banerjee, B. P. Eyden et al., "A study of four cases of extra-orbital giant cell angiofibroma with 
documentation of some unusual features," Histopathology, vol. 39, no. 4, pp. 390-396, 2001.

[9] H. R. Shu, Q. T. Yang, Y. Y. Lai et al., "Giant cell angiofibroma in the vocal cord," Chinese Medical Journal, vol. 123, no. 23, pp. 3479-3481, 2010.

[10] J. S. Silverman and A. Tamsen, "A cutaneous case of giant cell angiofibroma occurring with dermatofibrosarcoma protuberans and showing bimodal CD34+ fibroblastic and FXIIIa+ histiocytic immunophenotype," Journal of Cutaneous Pathology, vol. 25, no. 5, pp. 265-270, 1998. 


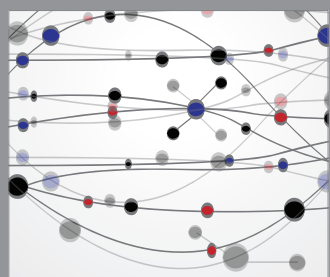

The Scientific World Journal
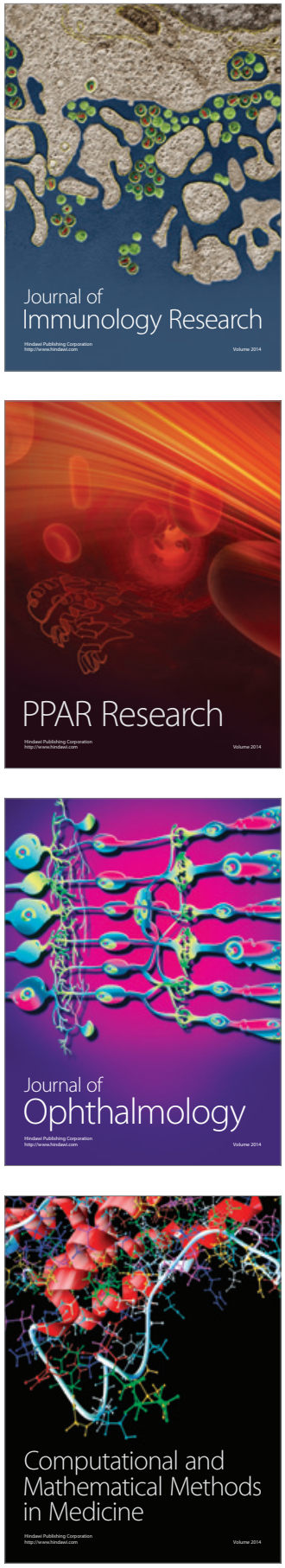

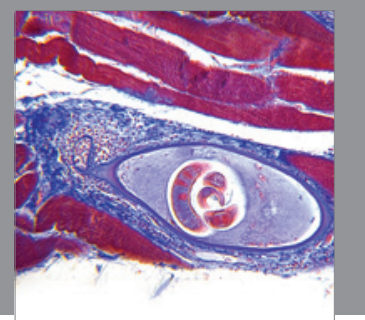

Gastroenterology

Research and Practice
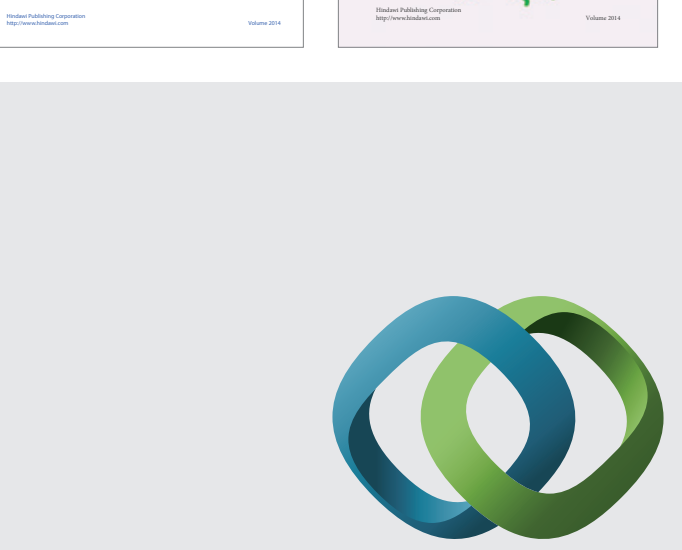

\section{Hindawi}

Submit your manuscripts at

http://www.hindawi.com
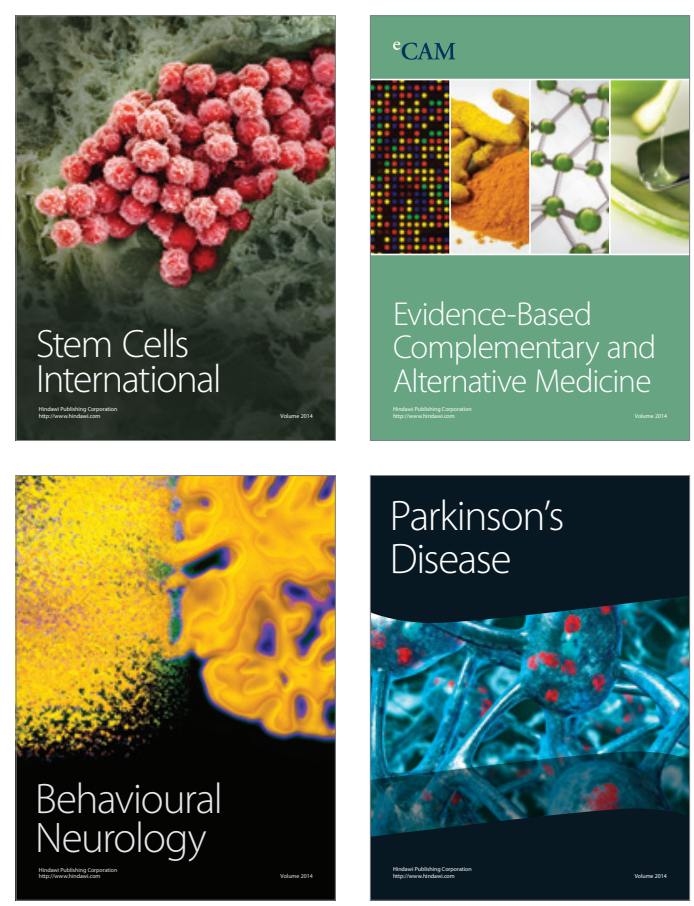

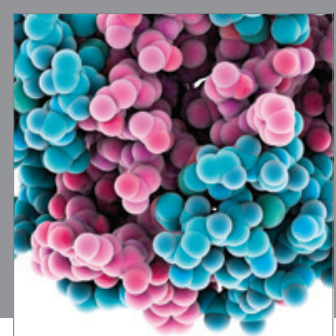

Journal of
Diabetes Research

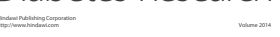

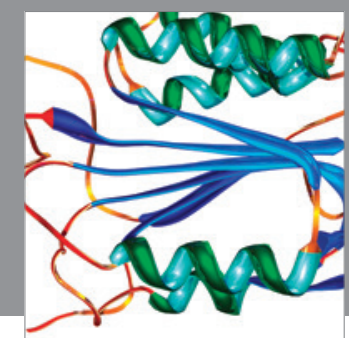

Disease Markers
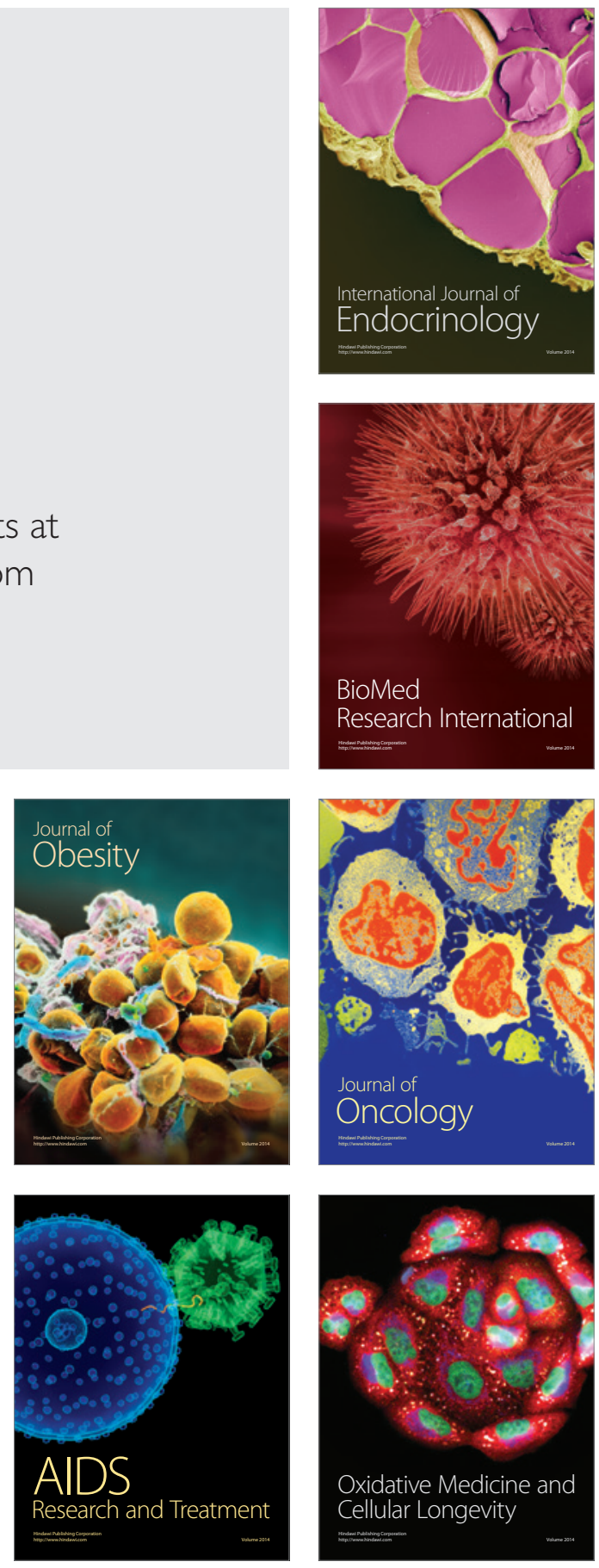